\title{
ANALISIS SUHU MUKA LAUT SELATAN JAWA DAN PENGARUHNYA TERHADAP CURAH HUJAN DAS CITARUM
}

\author{
Djazim Syaifullah ${ }^{1}$
}

\begin{abstract}
Analysis of Sea Surface Temperature (SST) south of Java and its influence on rainfall in the Citarum watershed has been done Sea surface temperature in the area bounded by $90 S$ to 120 S latitude and $1050 E$ to $1140 E$ longitude, on the border of this area closest to the island of Java. History analysis has done to see the rainfall history of Citarum river basin, while the analysis of time series used to see annual patterns, seasonal pattern and other patterns. It also performed spectral analysis to see clearly the pattern of rainfall. Against the sea surface temperature data are also performed a similar analysis. The analysis showed that the rainfall of Citarum watershed has a dominant period of the annual and the second is about three years. The analysis of the sea surface temperatures show an average maximum temperature reached $29.3^{\circ} \mathrm{C}$ occurred in early March and the lowest temperature reached $26.2^{\circ} \mathrm{C}$ occurred in midSeptember. The spectral analysis of sea surface temperature showed that in addition to the annual repetition appears also seasonal and cycles of some years although not obvious. Correlation of rainfall with sea surface temperature has a value ranging from 0.37 to 0.64 . Against latitude the biggest correlation value contained in latitude $08^{\circ} \mathrm{S}$ while against longitude the largest correlation seen in $112^{\circ} \mathrm{E}$.
\end{abstract}

\section{Intisari}

Analisis suhu muka laut (Sea Surface Temperature SST) wilayah selatan Jawa dan pengaruhnya terhadap curah hujan di Daerah Aliran Sungai (DAS) Citarum telah dilakukan. Suhu muka laut daerah selatan Jawa dibatasi mulai lintang $9^{\circ} \mathrm{LS}$ sampai dengan $12^{\circ} \mathrm{LS}$, bujur $105^{\circ} \mathrm{BT}$ sampai dengan $114^{\circ} \mathrm{BT}$, daerah ini yang berbatasan paling dekat dengan pulau Jawa. Data curah hujan DAS Citarum yang dipakai adalah data bulanan selama 19 tahun. Analisis historis untuk melihat curah hujan historis DAS Citarum sedangkan analisis time series digunakan untuk melihat pola tahunan (annual), pola musiman (seasonal) maupun pola yang lainnya. Selain itu juga dilakukan analisis spektral untuk melihat secara jelas pola curah hujannya. Terhadap data SST juga dilakukan analisis yang sama. Setelah itu dilakukan korelasi antara nilai SST masing-masing grid dengan curah hujan DAS Citarum. Hasil analisis menunjukkan bahwa curah hujan DAS Citarum mempunyai periode yang dominan yaitu tahunan (annual) dan yang kedua adalah sekitar tiga tahunan. Analisis terhadap suhu muka laut menunjukkan rerata suhu maksimum SST mencapai $29.3^{\circ} \mathrm{C}$ terjadi pada awal bulan Maret dan suhu minimum mencapai $26.2^{\circ} \mathrm{C}$ terjadi pada pertengahan bulan September. Hasil analisis spektral menunjukkan bahwa selain perulangan tahunan, suhu muka laut juga mengalami perulangan musiman dan perulangan beberapa tahunan meskipun tidak tampak jelas. Korelasi curah hujan dengan suhu muka laut mempunyai nilai berkisar antara 0.37 sampai dengan 0.64. Nilai korelasi terbesar terdapat pada lintang $08^{\circ} \mathrm{LS}$ sedangkan terhadap bujur, korelasi terbesar terlihat pada bujur $112^{\circ} \mathrm{BT}$.

Keywords : Suhu muka laut, curah hujan, spectral analisys

\section{PENDAHULUAN}

\subsection{Latar belakang}

\footnotetext{
${ }_{1}$ Peneliti Madya UPT Hujan Buatan, BPPT, djazimsy@ yahoo.com
}

Hujan berasal dari awan; awan berasal dari uap air yang mengembun di udara; uap air berasal dari air. Air yang paling banyak terdapat di laut. Dengan demikian peran laut dalam memproduksi uap air menjadi sangat penting, dan mempunyai jarak dekat dalam rangkaian proses pembentukan 
hujan. Khususnya untuk wilayah Sumatra Barat, lautan India adalah lautan di sekitarnya yang paling dekat.

Dalam skala besar, suhu lautan Samudera Indonesia dan suhu lautan Samudera Pasifik mempunyai kaitan yang dekat dalam rangkaian proses lautan, yang sampai saat ini kaitan tersebut banyak dihubungkan dengan fenomena El Nino maupun La Nina; sedangkan secara global kenaikan suhu muka laut dapat menyebabkan terjadinya perubahan iklim secara tidak langsung. Angin sebagai variable atmosfer mempunyai kaitan lebih dekat dengan perubahan tekanan maupun perpindahan massa uap air. Meskipun demikian keterkaitan antar variabel atmosfer akan menimbulkan dinamika atmosfer yang dikenal dengan cuaca dan iklim.

Perubahan tekanan dalam skala besar berkaitan dengan fluktuasi tekanan yang dikenal dengan Osilasi Selatan, yakni beda tekanan yang berfluktuasi antara Darwin (yang merepresentasikan sebelah barat) dengan Tahiti (yang merepresentasikan sebelah timur).

Pengeluaran bahang sebagai proses perpindahan bahang dari laut ke atmosfer menimbulkan pendinginan permukaan yang besarnya sebanding dengan besarnya penguapan. Laju penguapan sebagai perpindahan bahang dari lautan ke atmosfer sebesar rata-rata $1 \mathrm{~m} /$ tahun atau sekitar $2.7 \mathrm{~mm} /$ hari. Namun demikian uap air didalam atmosfer tidak terus bertambah. Berdasarkan perhitungan (Oort 1971 dikutip Gill 1982) menyatakan bahwa jumlah uap air yang menjadi curah hujan di permukaan bumi setebal $23 \mathrm{~mm}$; dengan demikian waktu tinggal (residence time) uap air di dalam atmosfer kira-kira sebesar $23 \mathrm{~mm} / 2.7 \mathrm{~mm}$ per hari $=8$ hari.

Uap air dalam atmosfer akibat proses penguapan tersebut yang menjadi modal dalam dinamika atmosfer dalam pembentukan awan dan hujan. Semakin besar laju penguapan di daerah tersebut maka semakin besar kandungan uap air yang tinggal di atmosfer daerah tersebut. Dengan adanya perpindahan massa udara (angin) maka terjadilah perpindahan uap air. Laju penguapan terbesar terjadi di lautan, semakin luas lautan maka semakin besar penguapannya, seperti disebutkan dimuka lautan luas yang paling dekat dengan wilayah Daerah Aliran Sungai (DAS) Citarum Samudera Indonesia.

Proses penguapan terjadi karena pemanasan permukaan air, semakin tinggi pemanasan maka akan semakin besar proses penguapan, semakin tinggi pemanasan juga akan semakin meningkatkan suhu permukaan air. Sehingga proses pengapan air laut dapat dilihat dari suhu permukan laut tersebut (Sea Surface Temperature - SST). Dengan demikian SST sangat penting untuk melihat konvektivitas wilayah tersebut dan tingkat pertumbuhan awan dan hujan.

Tujuan dari penelitian ini adalah melakukan analisis suhu muka laut (SST) di sebelah selatan Pulau Jawa dan melihat pengaruhnya terhadap curah hujan wilayah DAS Citarum, karena lautan di sebelah selatan Jawa merupakan lautan terdekat dengan wilayah DAS Citarum.

\subsection{Daerah Penelitian}

Daerah penelitian adalah Samudera Indonesia, lautan di selatan Pulau Jawa dan DAS Citarum Jawa barat. Suhu Muka Laut (Sea Surface Temperature SST) daerah selatan Jawa dibatasi mulai lintang $9^{\circ} \mathrm{LS}$ sampai dengan $12^{\circ} \mathrm{LS}$, bujur $105^{\circ} \mathrm{BT}$ sampai dengan $114^{\circ} \mathrm{BT}$, daerah ini yang berbatasan paling dekat dengan pulau Jawa sehingga mempunyai

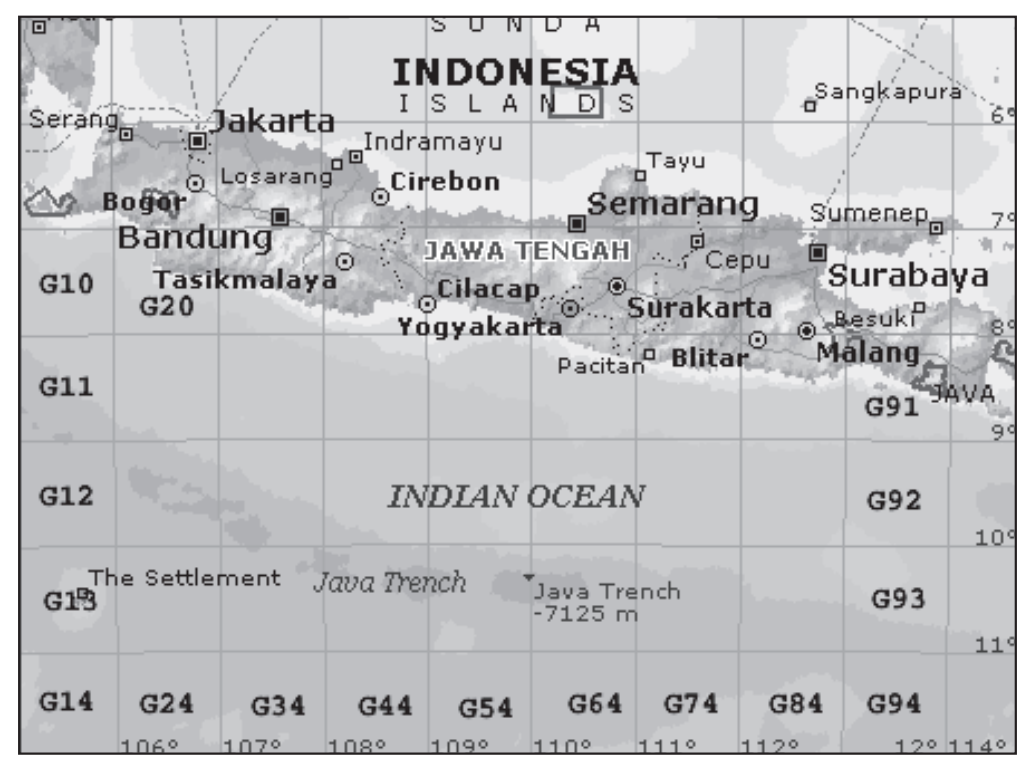

Gambar 1. Peta daerah penelitian, resolusi data 1 x 1oLintang, Indek Gij menunjukkan posisi grid 
pengaruh yang cukup besar terhadap supplay uap air dan pertumbuhan awan serta hujan di DAS Citarum yang terletak di Jawa barat..

\section{DATA DAN METODE}

\subsection{Data Curah Hujan DAS Citarum.}

Data curah hujan DAS Citarum yang dipakai adalah data bulanan selama 19 tahun (1986 sampai 2003) dengan 33 buah stasiun yang diperoleh dari beberapa sumber yaitu : UPT Hujan Buatan BPPT, Badan Meteorologi Klimatologi dan Geofisika (BMKG), Puslitbang Air Departemen PU dan dari berbagai sumber lainnya.

Panjang data bervariasi antara 10 sampai 30 tahun, setelah dilakukan stratifikasi data diperoleh data bulanan untuk curah hujan wilayah DAS Citarum dengan kualitas data yang memadai dengan panjang data selama 19 tahun dari 33 buah stasiun.

\subsection{Data Suhu Muka Laut (SST) Selatan Jawa}

Data suhu muka laut (SST) diperoleh dari website University Corporation for Atmospheric Research (UCAR), Colorado USA yang terdapat di situs : http://dss.ucar.edu/datasets/ds277.0/ dengan skala spasial $1^{0}$ derajat dan skala temporal mingguan. Data SST ini merupakan hasil analisis dengan menggunakan optimum interpolation diproses setiap minggunya. Analisis dilakukan terhadap pengamatan satelit in situ ditambah dengan simulasi SST terhadap tutupan es, sebelum analisis dihitung data satelit disesuaikan terhadap bias dengan menggunakan metode Reynolds (1988) dan Reynolds and Marsico (1993). Sampai tulisan ini dibuat metode optimum interpolasi sudah mencapai versi 2 dengan nama filenya adalah : oisst.\{yyyymmdd\}, dimana \{yyyymmdd\} adalah tahun, bulan dan tanggal pertengahan minggu. File terkompres dalam bentuk tar.

File-file tersebut ditulis dalam standar biner IEEE (big-endian). Setiap file berisi empat record yang dapat dijelaskan sebagai berikut:

record 1 : tanggal dan versi data / OIV2 (8 kata integer 4-byte).

record 2 : nilai SST di setiap grid ${ }^{0}$ geografi (360 x 180, 4 byte real words)

record 3 : error varians yang ternormalisasi (360 x 180,4 byte real words) record 4 : es konsentrasi di setiap gridnya (360 x 180,1 byte integer words)

Tidak ada analisis terhadap permukaan tanah (daerah daratan), nilai di permukaan tanah dikosongkan dengan interpolasi Cressman untuk menghasilkan grid menyeluruh terhadap masingmasing grid. Daerah lautan dan daerah daratan ditentukan dengan sebuah land sea mask, yang isinya nilai numerik 1 untuk daerah lautan dan nilai numerik 0 untuk daerah daratan.

Disediakan program standar dalam bahasa Fortran untuk membaca format data tersebut dengan metode akses sekuensial (fortran sequential access), secara teknis masing-masing record dalam file tersebut (yang berisi parameter) dipisahkan dengan data kontrol 4 byte di awal nilai parameter tersebut yang mengindikasikan jumlah byte dalam masing-masing record. Tabel 1 berikut memberi informasi spesifikasi data SST yang digunakan dalam penelitian ini.

Tabel 1. Spesifikasi Data SST yang digunakan dalam penelitian ini.

\begin{tabular}{|l|l||}
\hline \multicolumn{1}{|c||}{ Parameter } & \multicolumn{1}{c||}{ Keterangan } \\
\hline \hline Jenis data & Sea Surface Temperature/SST \\
\hline Sumber data & N O A A \\
\hline Resolusi spasial & $1^{\circ}$ Geographyc \\
\hline Resolusi temporal & Mingguan \\
\hline Metode interpolasi & Optimum Interpolation \\
\hline Jml grid bujur & 7 buah (106BT $\sim 112 \mathrm{BT})$ \\
\hline Jml grid lintang & 4 buah (08LS $\sim 11 \mathrm{LS})$ \\
\hline & \\
\hline
\end{tabular}

\section{HASIL}

Analisis dilakukan terhadap data curah hujan bulanan DAS Citarum dan data SST. Analisis curah hujan DAS dengan melihat curah hujan DAS Citarum secara historis dan time series. Analisis historis untuk melihat curah hujan historis DAS Citarum sedangkan analisis time series digunakan untuk melihat pola tahunan (annual), pola musiman (seasonal) maupun pola yang lainnya. Selain itu juga dilakukan analisis spektral untuk melihat secara jelas pola curah hujannya. Terhadap data SST juga dilakukan analisis yang sama yaitu analisis time series dan analisis spektral. Setelah itu dilakukan korelasi antara nilai SST masingmasing grid dengan curah hujan DAS Citarum. 


\subsection{Analisis Historis dan Time Series Curah hujan DAS Citarum}

Analisis historis curah hujan DAS Citarum dilakukan dengan mengeplot curah hujan bulanan DAS Citarum seperti terlihat pada Gambar 2. berikut.

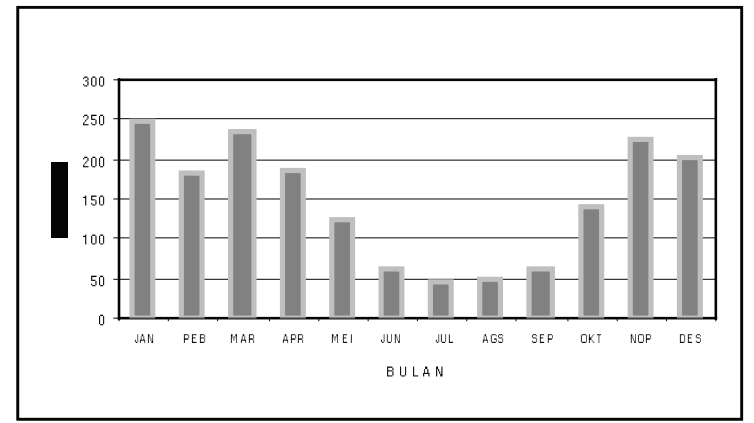

Gambar 2. Pola Curah Hujan DAS Citarum yang diambil dari 33 buah stasiun data bulanan selama 19 tahun (1986 2003)

Dari Gambar 2 secara historis terlihat bahwa DAS Citarum mempunyai curah hujan maksimum sebesar sekitar $250 \mathrm{~mm}$ yang terjadi pada bulan Januari. Curah hujan minimum terjadi pada bulan Juli sebesar sekitar $50 \mathrm{~mm}$. Kriteria Badan Meteorologi Klimatologi dan Geofisika (BMKG) untuk bulan kering adalah apabila dalam tiga dasarian (sepuluh harian) secara berturut-turut jumlah curah hujannya kurang dari $50 \mathrm{~mm}$, atau dengan kata lain dalam satu bulan jumlah curah hujannya kurang dari 50 $\mathrm{mm}$. Dengan kriteria tersebut, maka secara historis DAS Citarum memasuki musim kering pada bulan Mei sampai Oktober.

Analisis time series terhadap curah hujan DAS Citarum dapat dilihat seperti pada Gambar 3 , yang menunjukkan curah hujan bulanan DAS Citarum mulai tahun 1986 sampai awal tahun 2003.

Dari Gambar 3 terlihat bahwa selain pola tahunan (annual) yang kuat ternyata ada pola yang lebih panjang (beberapa tahunan) yang terlihat kurang jelas. Untuk melihat pola ulangan yang lebih jelas maka perlu dilakukan proses analisis periodisitas dengan menggunakan analisis spektral.

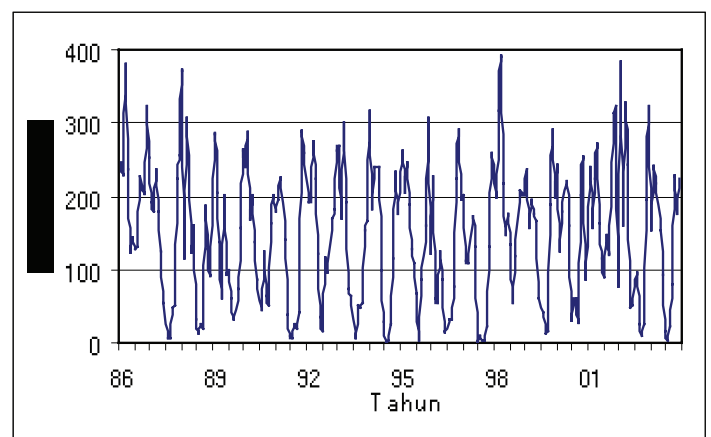

Gambar 3. Time series curah hujan bulanan DAS Citarum selama 19 tahun (1986 2003)

\subsection{Analisis Spektral Curah Hujan DAS Citarum}

Analisis spektral dilakukan untuk melihat secara jelas periodisitas dari data time series curah hujan DAS Citarum. Dengan analisis ini maka perulangan yang tampak kurang jelas dalam domain waktu (time domain) akan menjadi tampak jelas dalam domain frekuensi (frequency domain). Analisis spektral adalah suatu teknik untuk menganalisis perulangan atau periodisitas dari suatu gelombang harmonik dalam deret waktu (time series), teknik analisisnya adalah dengan melakukan transformasi gelombang harmonik deret waktu dari kawasan waktu (time domain) ke dalam kawasan frekuensi (frequency domain).

Transformasi ini dilakukan dengan Transformasi Fourier. Teknik ini telah banyak dikembangkan terutama oleh Cooley \& Tukey (1965). Untuk memudahkan menerapannya dalam data digital telah dikembangkan suatu teknik Transformasi Fourier Diskrit (Discrete Fourier Transform - DFT) dan Transformasi Fourier Cepat (FastFourierTransform-FFT)sebagai pemanfaatan sifat simetrisnya. Algoritma FFT untuk komputasi juga telah dikembangkan oleh Cooley, Lewis dan Welch (1969) pertama kali dalam bahasa Fortran, sehingga dapat dikembangkan oleh paket-paket program komputasi lain. Dewasa ini beberapa aplikasi matematika / sains (misalnya Matlab) telah memasukkan modul ini sehingga sangat mudah digunakan.

Seperti dimaklumi bersama bahwa untuk melihat perulangan di kawasan waktu cukup sulit dilakukan, di kawasan frekuensi perulanganperulangan ditunjukkan dengan puncak-puncak (peaks) dari suatu power density yang dihasilkan dari transformasi Fourier. Dengan melihat puncaknya akan segera diketahui pada frekuensi berapa perulangan tersebut dominan, jika frekuensinya diketahui maka periodenya dapat ditentukan.

Frekuensimaksimum $\left(\mathrm{f}_{\max }\right)$ adalah berbanding terbalik dengan interval sampling (v), yang dalam pernyataan matematiknya adalah :

$$
f_{\text {max }}=\frac{1}{v}
$$

Interval sampling di sini adalah satu bulan $(\mathrm{v}=1)$ karena datanya adalah bulanan (curah hujan maupun SST), sehingga dalam persamaan di atas frekuensi maksimum adalah satu bulan. Hal ini memberikan pengertian bahwa analisis spektral dengan interval sampling satu bulan tidak bisa melihat suatu ulangan yang periodenya kurang dari satu bulan. Gambar 4. menunjukkan hasil analisis spektral dari data time series curah hujan bulanan lebih dari 18 tahun. 


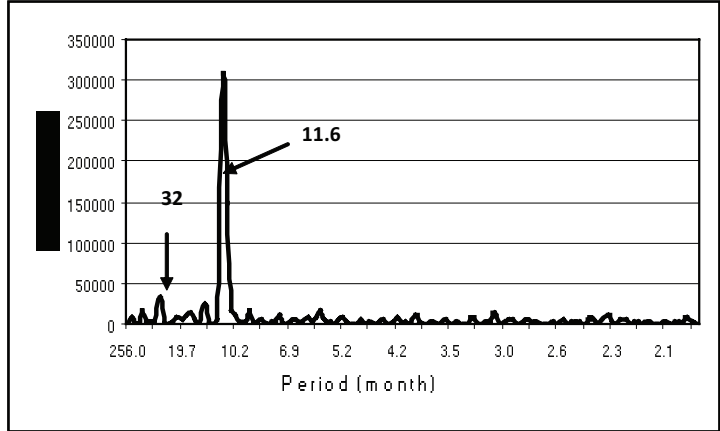

Gambar 4. Analisis Spektral curah hujan bulanan DAS Citarum

Dari Gambar 4 terlihat jelas bahwa puncak periodisitas terdapat pada nilai 11.6 dan 32 bulan. Ini menunjukkan bahwa periode yang dominan adalah tahunan (annual) dan yang kedua adalah sekitar tiga tahunan.

\subsection{Analisis Historis dan Time Series suhu muka laut selatan Jawa}

Analisis historis terhadap suhu muka laut dilakukan dengan mencari nilai rerata pada masing-masing grid setiap minggunya selama satu tahun dari data tahun 1986 sampai dengan 2003. Hasilnya di plot dalam Lampiran.

Rerata suhu maksimum SST di selatan Pulau Jawa mencapai $29.3^{\circ} \mathrm{C}$ terjadi pada awal bulan Maret dan suhu minimum mencapai $26.2^{\circ} \mathrm{C}$ terjadi pada pertengahan bulan September.

Analisis dilakukan dengan membuat profil SST historis untuk masing-masing lintang $\left(9^{\circ} \mathrm{LS}\right.$, $10^{\circ} \mathrm{LS}$ dan $\left.11^{\circ} \mathrm{LS}\right)$ pada grafik dengan bujur (longitude) yang sama untuk melihat apakah terjadi perubahan nilai SST terhadap lintang selama periode waktu tertentu. Disamping itu juga dibuat profil SST historis untuk masing-masing bujur (106 ${ }^{\circ} \mathrm{BT}, 1^{\circ} 7^{\circ} \mathrm{BT}, 1^{\circ} \mathrm{BT}, 109^{\circ} \mathrm{BT}, 1^{\circ} \mathrm{BT}, 1^{\circ}{ }^{\circ} \mathrm{BT}$, $112^{\circ} \mathrm{BT}$ ) pada grafik dengan lintang (latitude) yang sama untuk melihat apakah terjadi perubahan nilai SST terhadap bujur selama periode waktu tertentu. Gambar 5 adalah contoh nilai SST historis pada beberapa lintang $\left(9^{\circ} \mathrm{LS}, 10^{\circ} \mathrm{LS}\right.$ dan $\left.11^{\circ} \mathrm{LS}\right)$ untuk bujur $112^{\circ} \mathrm{BT}$.

Secara longitude nilai SST di wilayah Barat (sebelah Selatan Ujung Kulon) lebih dingin dibandingkan dengan SST di bagian Timur (Selatan Banyuwangi) pada bulan-bulan basah, sementara pada bulan-bulan kering terjadi sebaliknya. Pada bulan basah suhu muka laut di sebelah timur lebih tinggi dari sebelah baratnya, menyebabkan tekanan udara di sebelah timur lebih rendah dibandingkan sebelah baratnya. Hal ini bersesuaian dengan arah angin yang pada bulan-bulan basah bertiup dari arah Barat (Baratan).

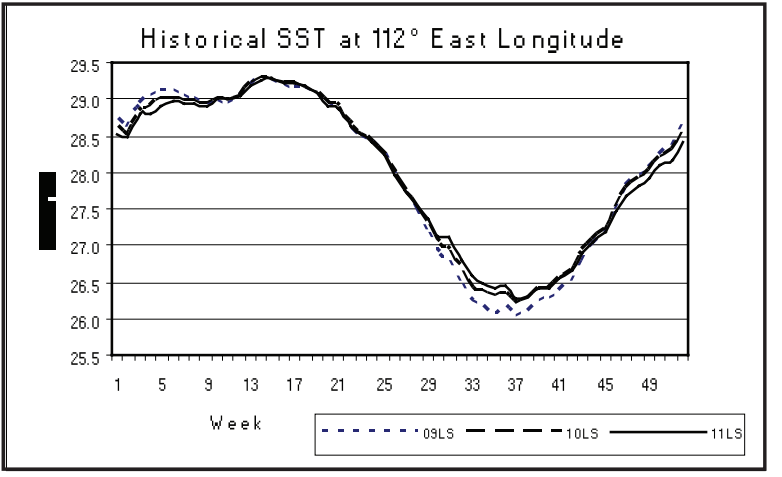

Gambar 5. Nilai SST historis pada beberapa lintang $\left(9^{\circ} \mathrm{LS}, 10^{\circ} \mathrm{LS}\right.$ dan $\left.11^{\circ} \mathrm{LS}\right)$ untuk bujur $112^{\circ} \mathrm{BT}$

Secara Latitude nilai SST yang dekat dengan pantai lebih tinggi dibandingkan dengan di sebelah Selatan pada bagian Barat Pulau Jawa (seperti terlihat pada gambar di lampiran). Di sebelah Timur Pulau Jawa perbedaannya tidak begitu jelas.

Analisis time series terhadap suhu muka laut dilakukan dengan mengeplot data suhu muka laut secara time series seperti terlihat pada Gambar 6 . berikut ini.

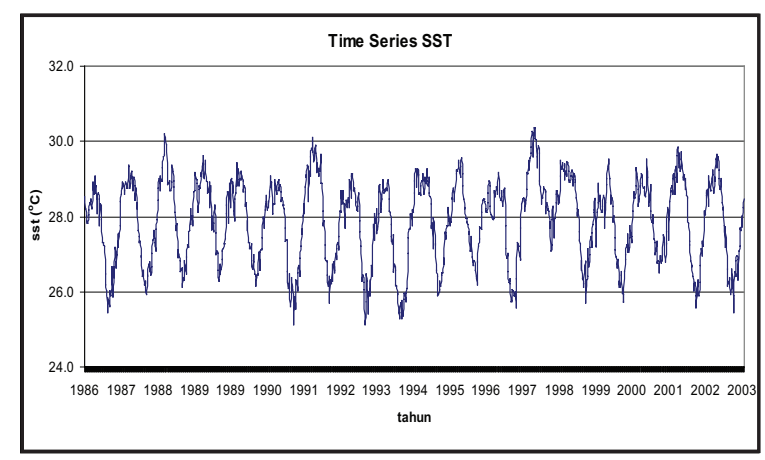

Gambar 6. Time series SST daerah Laut Selatan Jawa selama 19 tahun (1986 2003)

Gambar 6 menunjukkan plot time series nilai SST daerah laut selatan Jawa (rerata dari wilayah dengan batasan koordinat lintang 9oLS sampai dengan 12oLS, bujur 105oBT sampai dengan 1140BT ) selama 19 tahun. Dari gambar tersebut terlihat bahwa selain pola tahunan (annual) yang kuat ternyata ada pola lain yang lebih panjang yang terlihat secara tidak jelas.

Seperti halnya terhadap data curah hujan DAS Citarum, untuk melihat pola ulangan yang lebih jelas terhadap data SST, maka perlu dilakukan proses analisis spektral.

\subsection{Analisis spektral suhu muka laut selatan Jawa}

Analisis spektral dilakukan terhadap data suhu muka laut selatan Jawa. Metode yang sama dengan analisis spektral terhadap data curah hujan 
DAS Citarum dilakukan dengan transformasi Fourier Cepat (Fast Fourier Transform FFT) terhadap data suhu muka laut. Hasil analisis spektral disajikan pada Gambar 7.

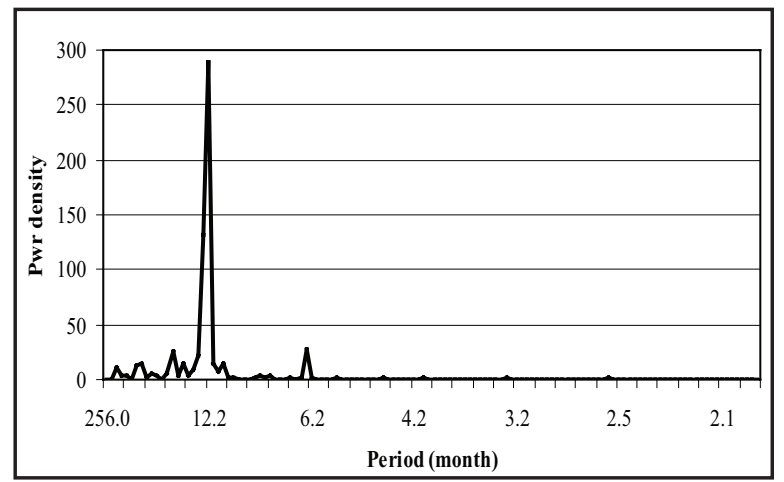

Gambar 7. Analisis Spektral suhu muka laut (SST) Selatan Jawa

Dari gambar tersebut dapat dilihat bahwa SST di selatan Jawa mempunyai nilai periodisitas di sekitar 12 bulan (terlihat pada puncak paling tinggi), disamping itu juga periodisitas 6 bulanan yang terlihat tidak terlalu kuat (puncaknya tidak terlalu tinggi). Periode yang lebih panjang dari 12 bulan (tahunan) terlihat beberapa periode meskipun tidak terlalu jelas. Dari hasil analisi ini menunjukkan bahwa selain perulangan tahunan, suhu muka laut juga mengalami perulangan musiman dan perulangan beberapa tahunan meskipun tidak tampak jelas.

\subsection{Korelasi dengan Curah Hujan Historis DAS Citarum}

Seperti disebutkan di muka bahwa faktor suhu muka laut dapat mempengaruhi proses konveksi di suatu tempat. Hasil akhir dari suatu proses konveksi berupa pertumbuhan awan dan hujan meskipun tidak semuanya menghasilkan curah hujan yang terukur, sehingga ada hubungan antara peristiwa konveksi dengan adanya kanaikan suhu muka laut dengan curah hujan yang terjadi di suatu daerah.

Untuk melihat keeratan hubungan antara suhu muka laut wilayah selatan Jawa dengan curah hujan DAS Citarum maka dilakukan korelasi antara keduanya. Korelasi dihitung untuk masing-masing grid terhadap curah hujan dengan menggunakan statistik sederhana. Tabel 2 menunjukkan nilai korelasi antara curah hujan DAS Citarum dengan nilai SST.

Dari hasil analisis korelasi data pada Tabel 2 menunjukkan bahwa nilai korelasi antara suhu muka laut selatan Jawa dengan batasan tersebut di atas dengan curah hujan DAS Citarum mempunyai nilai berkisar antara 0.37 sampai dengan 0.64.
Tabel 2. Nilai Korelasi Curah hujan DAS Citarum dengan nilai SST untuk setiap gridnya

\begin{tabular}{|c|c|c|c|c|c|c|c|c|}
\hline & \multicolumn{8}{|c|}{ Bujur Timur } \\
\hline \multirow{5}{*}{ 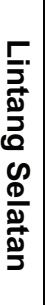 } & Grid & 106 & 107 & 108 & 109 & 110 & 111 & 112 \\
\hline & 08 & 0.44 & 0.47 & 0.51 & 0.54 & 0.57 & 0.61 & 0.64 \\
\hline & 09 & 0.42 & 0.45 & 0.49 & 0.53 & 0.56 & 0.60 & 0.64 \\
\hline & 10 & 0.39 & 0.42 & 0.46 & 0.49 & 0.53 & 0.57 & 0.61 \\
\hline & 11 & 0.37 & 0.40 & 0.44 & 0.47 & 0.49 & 0.53 & 0.57 \\
\hline
\end{tabular}

Nilai korelasi terbesar terdapat pada lintang $08^{\circ} \mathrm{LS}$ sedangkan terhadap bujur, korelasi terbesar terlihat pada bujur $112^{\circ} \mathrm{BT}$.

Secara latitude nilai korelasi grid yang dekat dengan daratan $\left(08^{\circ} \mathrm{LS}\right)$ lebih besar dibandingkan dengan grid yang lebih jauh, hal ini dapat dijelaskan bahwa lautan yang paling dekat dengan daratan mempunyai pengaruh lebih besar dibandingkan dengan lautan yang lebih jauh dengan daratan. Semakin tinggi suhu permukaan lautnya semakin banyak kandungan uap air di atmosfernya dan karena jaraknya dekat dengan daratan maka peluang sampai ke daratan dan menjadi modal pertumbuhan awan juga lebih besar. Secara Longitude belum bisa dijelaskan kenapa semakin ke arah timur nilai korelasi semakin besar.

\section{KESIMPULAN}

\subsection{Kesimpulan}

Curah hujan DAS Citarum maksimum terjadi pada bulan Januari sedngkan minimum terjadi pada bulan Juli, secara historis DAS Citarum memasuki musim kering pada bulan Mei sampai Oktober. Selain pola tahunan yang kuat ternyata ada pola yang lebih panjang (beberapa tahunan) yang terlihat kurang jelas.

Dari hasil analisis spektral terlihat bahwa curah hujan DAS Citarum dan suhu muka laut sama sama memiliki periodisitas tahunan (annual) yang kuat, pada curah hujan terlihat periodistias kurang kuat 32 bulan (sekitar tiga tahunan) sedangkan pada suhu muka laut selain perulangan tahunan, juga mengalami perulangan musiman dan perulangan beberapa tahunan meskipun tidak tampak jelas.

Korelasi curah hujan dengan suhu muka laut. mempunyai nilai berkisar antara 0.37 sampai dengan 0.64 . Nilai korelasi terbesar terdapat pada lintang $08^{\circ} \mathrm{LS}$ sedangkan terhadap bujur, korelasi terbesar terlihat pada bujur $112^{\circ} \mathrm{BT}$. Curah hujan wilayah DAS Citarum dipengaruhi oleh besarnya nilai suhu muka laut (SST) selatan Pulau Jawa. 


\subsection{Saran}

Perlu dilakukan analisis ini dengan menggunakan data yang lebih panjang lagi sehingga periodisitas yang lebih panjang aka terlihat.

\section{DAFTAR PUSTAKA}

Cooley, J. W. and Tukey, J. W., 1965 : An Algorithm for the machine calculation of complex Fourier series. Mathematics of Computation, 19, 297-301

Cooley, J. W., Lewis, P. A. and Welch, P. D., 1969 : The Fast Fourier Transform and its applications. IEEE Trans. on Education 12, 27-34
Gill, A.E., 1982: Atmosphere-Ocean Dynamics. International Geophysics Series, Vol. 30. Academic Press.

Reynolds, R. W., 1988: A real-time global sea surface temperature analysis. J. Climate, 1 , 75-86.

Reynolds, R. W. and D. C. Marsico, 1993: An improved real-time global sea surface temperature analysis. J. Climate, 6, 114 119.

University Corporation for Atmospheric Research (UCAR), Sea Surface Temperature Data, http://dss.ucar.edu datasets/ds277.0/ di akses di situs pada tanggal 4 Agustus 2009. 

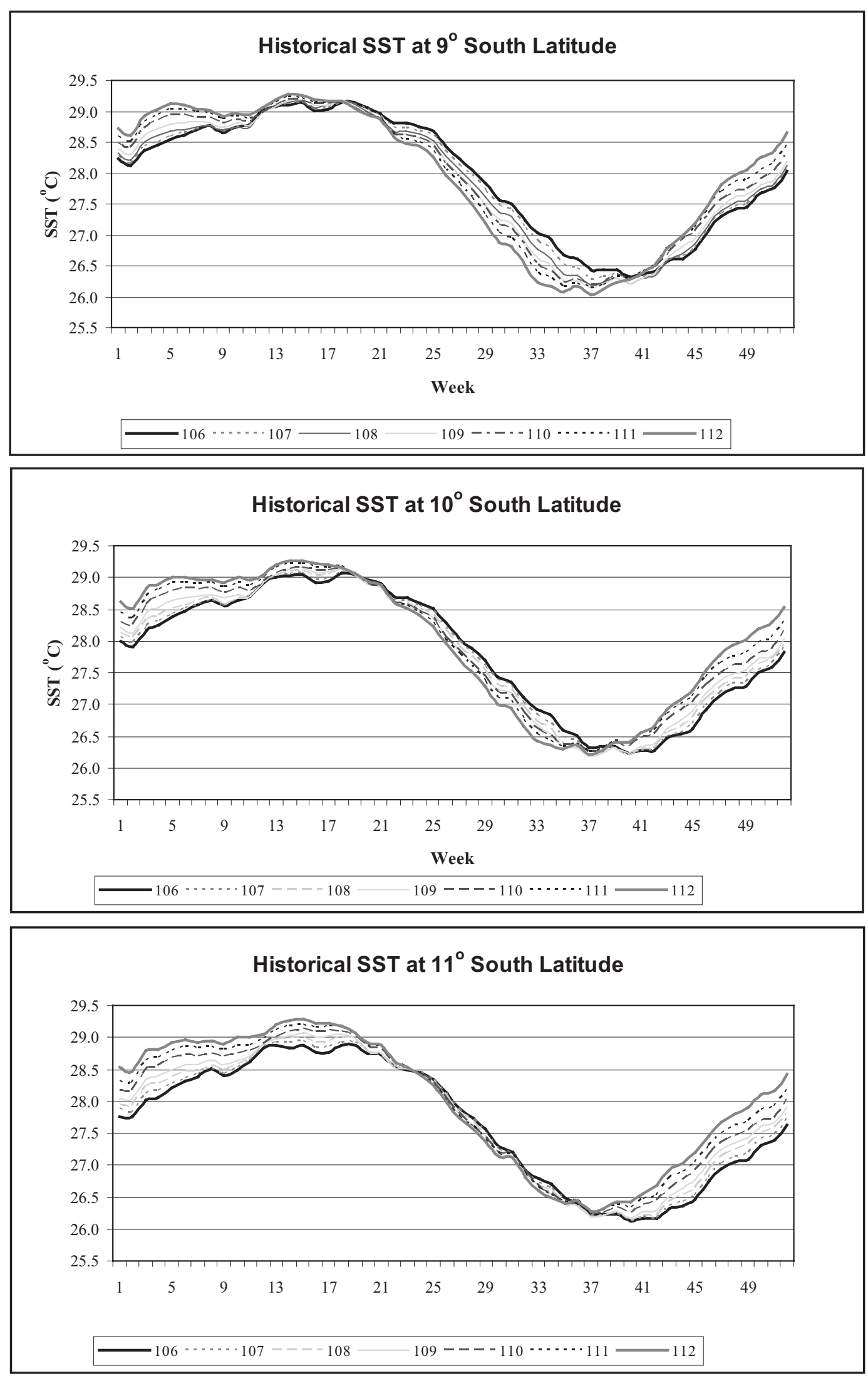

Gambar L1. Profil Longitude nilai SST historis untuk lintang $9^{\circ} \mathrm{LS}, 10^{\circ} \mathrm{LS}$ dan $11^{\circ} \mathrm{LS}$ 
Analisis Suhu Muka Laut Selatan ... (Djazim Syaifullah)
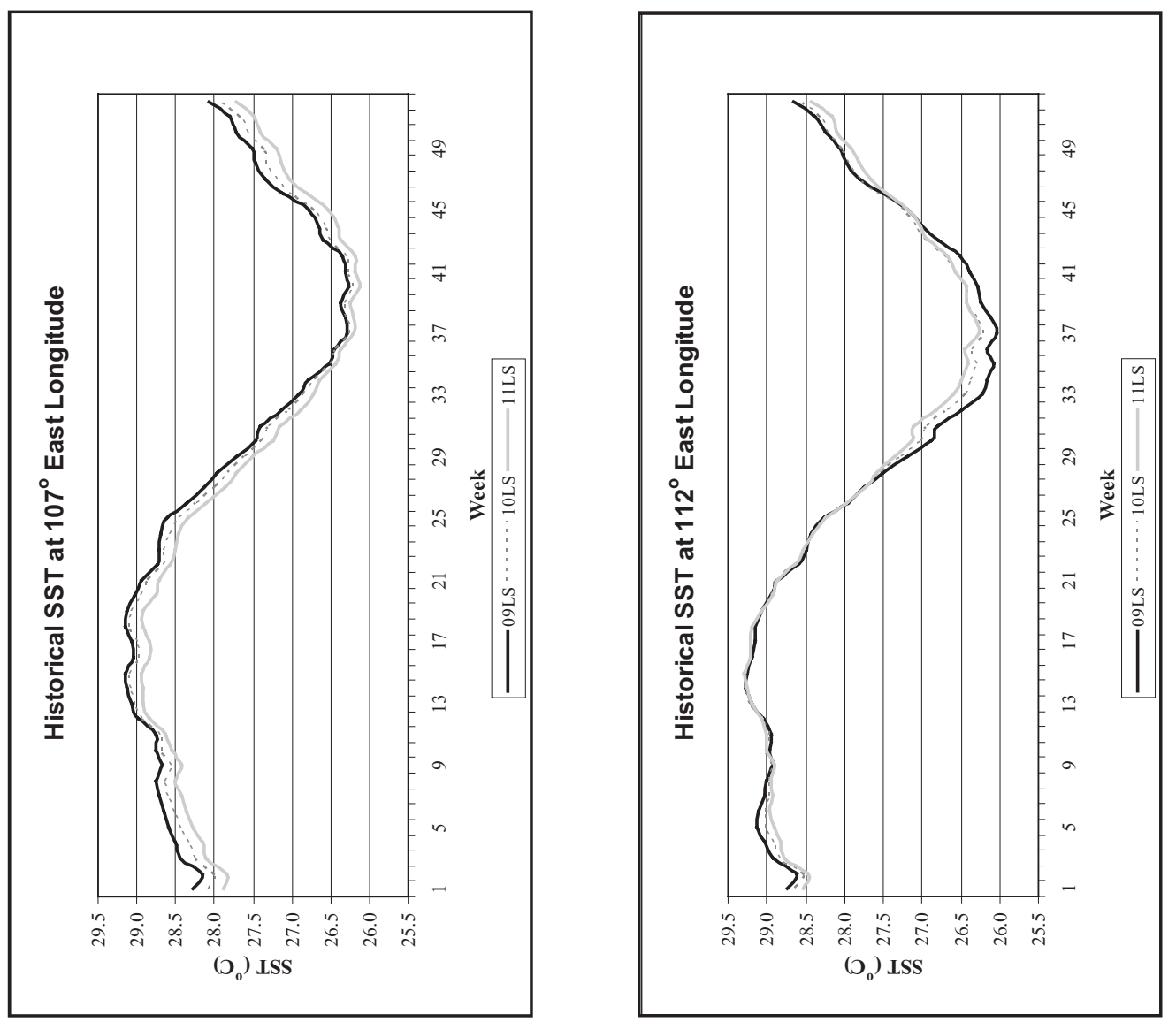

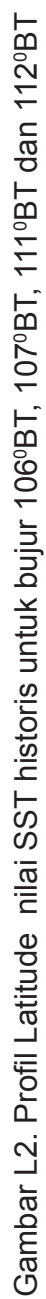
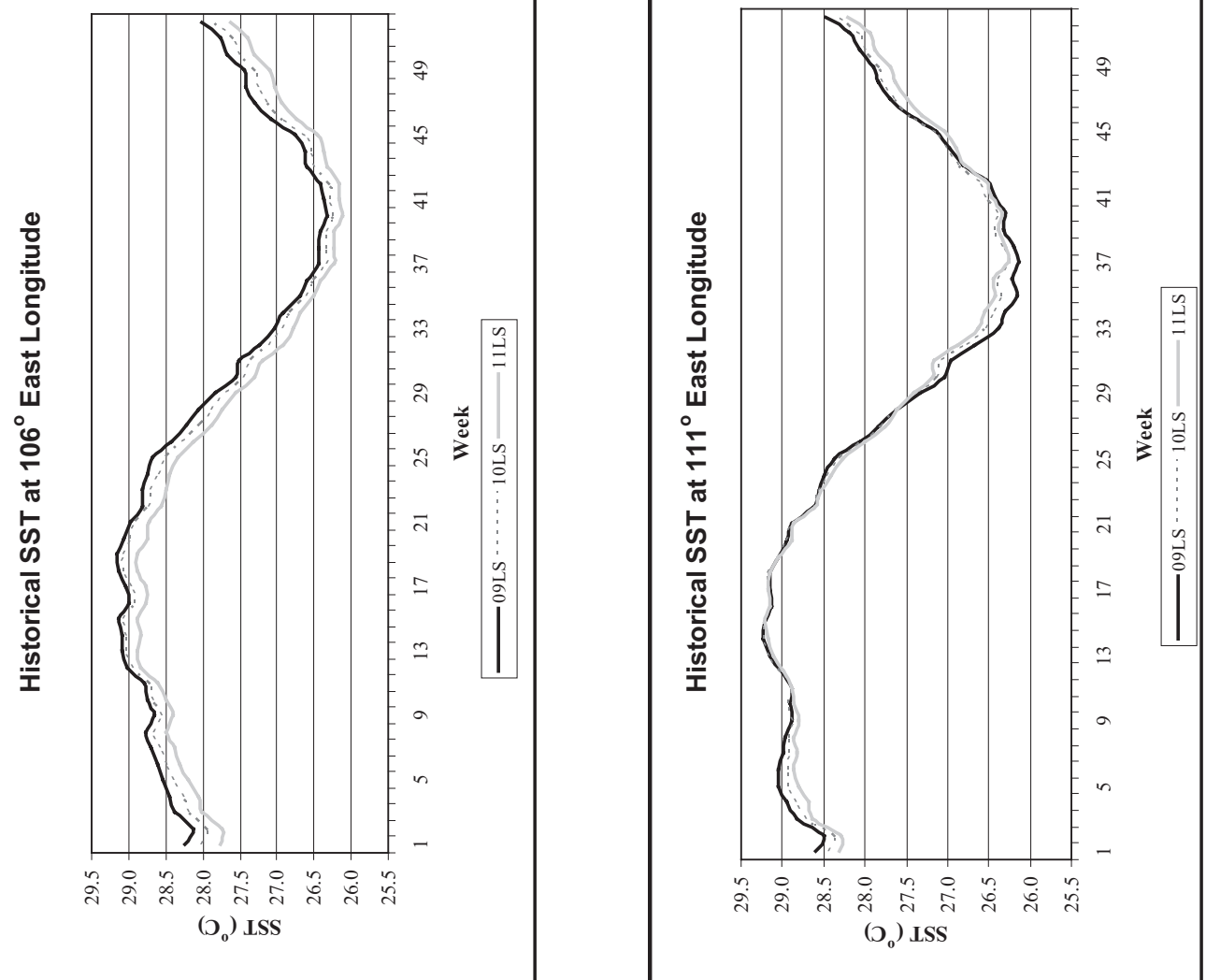
